811.163.41(497.16)

$81^{\prime} 272(497.16)$

https://doi.org/10.18485/sj.2021.26.1.33

БУДИМИР Р. АЛЕКСИЪ *

Српска православна богословија

„Свети Петар Цетињски”

Цетиње, Црна Гора
Оригинални научни рад

Примљен: 13. 10. 2020.

Прихваћен: 12. 1. 2021.

\title{
О ИМЕНОВАњУ ЈЕЗИКА У ПРОШЛОСТИ ЦРНЕ ГОРЕ И БОКЕ КОТОРСКЕ
}

У овом раду се разматра питање именовања матерњег језика у прошлости Црне Горе и Боке Которске. Анализом сачуваних извора од XV вијека до данас долази се до закључка да су Црногорци и Бокељи свој језик увијек називали српским (а никад „црногорским”). Све историјске чињенице необориво доказују и потврђују да је српски језик био у службеној употреби у Књажевини (Краљевини) Црној Гори за читаво вријеме њеног постојања.

Кључне ријечи: српски језик, српски народ, ћирилично писмо, Црна Гора, Бока Которска, Црногорци, Бокељи, службена употреба језика.

1. Током читаве црногорске историје, од времена Црнојевића до 1918. године, владало је мишљење да су Црногорци не само интегрални него елитни дио српског народа. То су увјерење ширили сви црногорски владари - владике и господари; писци, публицисти, историчари, - и домаћи и страни. Штавише, све до треће деценије XX вијека, никоме није падало на памет да мисли другачије. Стога се и њихов матерњи језик није могао именовати никаквим другим називом до његовом етничком атрибуцијом. Јер, назив сваког језика произлази из имена његовог народа, што је постало неприкосновено начело и у теорији и у пракси.

"b.aleksic@t-com.me 
2. У сачуваним изворима од XV вијека до данас постоји обиље доказа да су Црногорци свој језик називали српским (а никад „црногорским”) ${ }^{1}$. Указаћемо само на неколико докумената који репрезентативно свједоче како су Црногорци схватали и именовали свој матерњи језик.

Још је у тестаменту Ђурђа Црнојевића истакнуто да је његов „тестаментарни запис писан његовом властитом руком, на српском језику, а на латински од ријечи до ријечи преведен, онако како стоји” (види „Тестамент Ђурђа Црнојевића" у: Мартиновић 2009: 28) (сва истицања масним словима су моја - Б. А.).

О језичком идентитету Црне Горе и Приморја свједочи и чињеница да је први српски Буквар, инока Саве Дечанца, настао у манастиру Градишту у Паштровићима, штампан (у Венецији 1597) на српскословенском језику и да су предлошци несумњиво српски. Овај Буквар је сачуван на четири листа, на којима је изложен систем српскословенске ћирилице (о томе опширније у: Алексић 2016).

Црногорски сердар Станко Радоњић пише 1753. године которском провидуру. Уврх превода тога писма стоји да је то писмо „превод са српског језика" (цит. према: Петровић Д. 1996а: 49).

Цетињски митрополит Сава Петровић (1735-1744, 1766-1781), други по реду митрополит из владичанске куће Петровића, у писму Дубровчанима од 15. јуна 1767. каже: „И драго нам је владање ваше који се ви јоште од нашега србскога језика находите" (цит. према: Јовановић 1986: 65).

А Јован Стефанов Балевић (родом из Братоножића), први доктор философије у Срба, у спису „Кратак и објективан опис садашњег стања Црне Горе", написаном 29. јула 1757. године, истакао је да у Црној Гори свештеници уче „читање и писање на славеносрпском језику” (цит. према: Петровић Р. 1997: 126-132).

Двадесет писама Светог Петра Цетињског (као и три писма која је писао његов секретар - опат Франо Долчи) упућених 1801. и 1802. године тадашњој аустријској власти у Котору налазе се у Архиву Хрватске, у једној фасцикли са ознаком „Е” и са насловом „Писма владике Црне Горе генералу команданту г. Николетију". Та документа садрже преводе писама на италијански језик, а на самим документима, и то на листовима 1, 2, 46 и 47, службеном забиљешком је констатовано да су ова писма преведена „са српског језика” („dal Serviano”) (цит. према: Павићевић 2011: 24). У вријеме Светог Петра Цетињског, најмлађи Црногорци су стицали прва знања из „Српског буквара” штампаног у Венецији 1812. године.

${ }^{1} \mathrm{O}$ именовању српског језика у прошлости Црне Горе и Боке Которске видјети и радове: Петровић 1996а: 48, 49 и 65; Алексић 2008: 641-646; Стојановић 2016: 308-313. 
Његош је 1836. године, „у митрополитској књигопечатњи” на Цетињу, штампао „Српски буквар”, а двије године касније (1838) и „Српску граматику”, састављену „за црногорску младеж”. Овај највећи српски пјесник је дао мишљење о свом матерњем језику, па, дакле, и о језику Црногораца. Он je, наиме, на календару „Даница” из 1826. године, уз посвету епископу ужичком Никифору (Максимовићу) о Ђурђевдану 1833. године (види подробније у: Дурковић Јакшић 1980: 25-58), умјесто потписа, написао сљедеће стихове (наводимо их према критичком издању Радмила Маројевића (Маројевић 2019a:175-176)):

\author{
Име ми је Верољуб, \\ презиме ми ј' Родољуб; \\ 2 Црну Гору, родну груду, \\ камен паше одасву̀дӯ. \\ Србски пишем ѝ зборйм - \\ сваком громко говорим: \\ 4 народност ми ј' срेб' јйнска̄, \\ ум и душа - славјанска.
}

О називу матерњег језика Црногораца свједочи један документ из 1857. године који се чува у Државном архиву Црне Горе на Цетињу. Ријеч је о писму књаза Данила Петровића од 15. маја 1857. упућеном „Србском Правитељству", односно Влади Кнежевине Србије, у коме овај књаз Црне Горе и Брда, након повратка из Париза, тражи од „Србског Правитељства” да му пошаље једног професора из Србије како би надокнадио своје нередовно школовање лекцијама из граматике и правописа српског језика. У том писму књаз Данило, поред осталог, каже: „По возвратку мојега путешествија у Црну Гору намјеравам узети једног добро у србском језику искусног професора за мене, који је совршено учитељске предмете изучио и који ће ми лекције формално предавати" (Драгићевић 1952: 372).

Важан документ о језику Црногораца јесте и Земљопис Књажевине Црне Горе за ученике трећег разреда основне школе из 1895. године. У том извору пише да „у Црној Гори живе све сами чисти и прави Срби, који говоре српским језиком" (Поповић/Рогановић 1895: 31).

И у Читанции за други разред основнијех школа, коју је саставио Ђуро Поповић, штампаној на Цетињу 1897. године, стоји: „Ми говоримо српскијем језиком, а ко год је од матере своје научио, још од малена, српски говорити, тај је Србин. Пошто сви људи у нашем завичају говоре српскијем језиком, то је народ у нашем завичају српски" (Поповић 1897: 80).

На Цетињу је 1900. године објављена Српска граматика за трећи и четврти разред основнијех школа у Кьажевини Црној Гори, коју је саставио Ђуро Шпадијер. На питање: „Шта је то српска граматика” даје се одговор: 
„Српска граматика је наука, која нас учи, да правилно српски говоримо, пишемо и читамо” (Шпадијер 1900: 7).

Да је у свим црногорским школама у употреби био српски језик потврђује и Закон о народнијем школама у Краљевини Црној Гори из 1911. године. У Закону пише да је задатак „народнијема школама, да васпитавају дјецу у народном и религијском духу и да их спремају за грађански живот, а нарочито да шире просвету и српску писменост у народу" (Закон о школама 1911: чл. 1) и да се у основној школи, поред осталих предмета, уче српски језик и српска историја (Закон о школама 1911: чл. 26).

Велики руски научник Павле Аполонович Ровински (1831-1916), историчар, етнограф и лингвиста, који је више него иједан научник, и у Црној Гори и ван ње, проучавао Црну Гору и о њој објавио замашно дјело, испитивао је, поред осталог, и језик Црногораца, о којему је објавио доста опширну студију која је преведена и смјештена у III том његове капиталне књиге Црна Гора у прошлости и садашњости. На самом почетку те студије Ровински наглашава: „Језик, којим се говори у Црној Гори, представља посебан говор јужног српског штокавског нарјечја, у коме се $\mathbf{b}$ изговара као је а не као $u$. Највише личи на херцеговачки, али се и од њега разликује по неким особинама. По тим карактеристикама нећемо наћи ништа такво, што не бисмо нашли појединачно и у другим говорима српског језика” (Ровински 2004: 633).

Принц Михаило Петровић-Његош (1908-1986), унук краља Николе, као и сви његови преци, свој матерњи језик назива српским. Говорећи у својим мемоарима о свом школовању у Енглеској, он каже да је након извјесног времена у завод дошао пријатељ његове породице, Никола Ђорђевић, који се „старао да обнови наше знање српског језика, који смо мало по мало били заборавили у корист француског, италијанског и енглеског” (Петровић 2001: 35).

Све расположиве историјске чињенице, дакле, необориво доказују и потврђују да је српски језик био у службеној употреби у Књажевини (Краљевини) Црној Гори за читаво вријеме њеног трајања. Томе у прилог навешћемо и један међудржавни уговор који за нашу тему представља извор првог реда. Ријеч је о Конкордату (уговору) који је Књажевина Црна Гора потписала с Ватиканом 18. августа 1886. године, а којим је регулисан положај римокатолика у Црној Гори. У члану 12. тог уговора говори се о школовању будућих римокатоличких свештеника које ће стипендирати црногорска влада, па се, поред осталог, каже: „За првијех пет година, бројећи од датума овога Уговора, шиљаће се по два младића сваке године, а послије само по један сваке године. Ти младићи биће обавезани да у Риму уче и српски језик” (Џомић 2013: 107). Из овога се јасно види који је језик био у службеној употреби у Црној Гори онога времена. 
На првом попису становништва у Књажевини Црној Гори, одржаном 1909. године, националност је одређивана према матерњем језику. Сви који су српски језик наводили као матерњи - по националности су били Срби. Исказано у процентима, 95 одсто грађана се изјаснило да им је матерњи језик — српски (о томе видјети: Шијаковић 2011: 825).

Указаћемо на још један документ који потврђује чињеницу да је српски био службени језик свих организација, институција и удружења у Књажевини и Краљевини Црној Гори. Наиме, како извјештава Цетиғски вјесник од 5. фебруара 1914. године, на Цетињу је „иницијативом представника свих грађанских сталежа (...) основано Српско соколско друштво" (цит. према: Јовановић 1986: 285). У правилима тог друштва каже се, поред осталог, да „чланом друштва може бити сваки Србин и Српкиња и сваки пријатељ српског народа, који су навршили 18-ту годину живота, а који нијесу били судски кажњени. (...) Друштвена обиљежја јесу: 1) друштвена застава: Српска народна тробојница (црвено-плаво-бијела) (...). Службени је језик српски, писмо ћирилицом. Друштвена је слава Видовдан, 15. јуна сваке године” (цит. према: Јовановић 1986: 285).

Употреба израза српски језик, којим се именује језик Црногораца, у писаним документима од XV вијека, односно од времена Црнојевића до краља Николе (дакле у дугом временском периоду од око 450 година), и то управо у службеним списима, јавним исправама и уџбеницима, истовремено је стварни показатељ њихове објективне националне припадности. „Потпуно је извјесно да у том времену немамо ни један податак да се становништво (старе) Црне Горе у етничконационалном смислу називало друкчије осим као Срби", наглашава водећи савремени српски лингвиста Радмило Маројевић (2019б: 58).

Да се у Црној Гори српски језик тако службено називао од око 1830. до 1923. године и од 1945. до 1960. потврђује и др Милорад Никчевић, један од водећих заговорника „црногорског језика” (Никчевић М. 1992: 9).

И Црногорци у дијаспори (дакле - ван српских земаља) увијек су се етнички и национално декларисали као Срби којима је стога матерњи језик српски (о томе видјети: Гојнић 1999; Барбалић 1933).

И Албанци у Црној Гори су језик сусједног словенског становништва увијек именовали као српски. То потврђује свједочење Катарине Љуљђурај (рођ. 1911) из 2012. године. Ова — тада најстарија мјештанка Малесије говори да ју је у дјетињству „мајка учила српски језик, а отац албански” (цит. према: Дабановић 2012).

3. Једнако као и Црногорци, и Бокељи су свој матерњи језик именовали као српски, о чему постоји обиље свједочанстава, почевши од XV вијека па до 
наших дана. Године 1412. деспот Ђурађ дарива властелину Медлу Анђеловићу село „Шушан више Будве”. Ово даровно писмо је писао Бокељ Никола Мирошевић који на крају писма додаје: „Ја Никола Мирошевић, канжалиер, писах српским језиком" (цит. према: Петровић Д. 1996а: 49). Познати венецијански издавач ћириличних књига Јеролим Загуровић (Котор, око 1500 - Венеција, 1572), „властелин од града Котора”, штампао је 1569. године Псалтир за који каже: „Ово се дјело зове на грчком језику Псалтир, а по српском језику Пијевац” (цит. према: Петровић Д. 1996а: 49). Године 1617. херцегновске аге и поглавице пишу которском провидуру, а испод тог писма стоји записано да је примљено из Новога и да га је превео Јероним Писарић - „државни тумач српског језика у овом граду Котору” (,dragomano publico della lingua serviana in questa città di Cattaro") (цит. према: Петровић Д. 1996a: 49).

Значајно свједочанство о називу језика у Боки Которској представља и исказ арцибискупа скопљанског (по свој прилици Петра Богданића, који је прије тога био барски арцибискуп) из 1685. године да је Херцег Нови у Србији и да се у њему говори „српски језик” (,se serve lingua serviana”) (цит. према: Петровић Д. 1996а: 49)). А 1770. године пише далматински управитељ из Котора млетачкој влади, и каже да му је Шћепан Мали писао „на српском језику" (цит. према: Петровић Д. 1996а: 49).

О борби Бокеља за свој српски језик свједочи и податак да су Ришњани званична акта на италијанском језику враћали непрочитана, правдајући се да их не разумију. Тако рисанска општина 1795. моли которског провидура да им убудуће акта шаље на народном језику, „по сербски”, објашњавајући да је то увијек био обичај (цит. према: Стојковић 2008: 67).

Дугогодишњи директор, и вјероватно најбољи познавалац Которског архива, Славко Мијушковић, говорећи о називу народног језика у Боки у документима Которског архива констатује сљедећу чињеницу: „За наш народни језик у старијим списима најчешће се јавља назив 'српски', али се понекад наилази и на израз 'илирски'; исто тако и у документима писаним на латинском и италијанском језику јављају се оба израза, који се негдје потпуно изједначавају" (Мијушковић 1965: 6). Мијушковић пише да су припадници градске интелигенције у Боки Которској за вријеме аустријске владавине били „жестоки поборници српског језика и ћирилице” (Мијушковић 1965: 7). Мијушковић износи податке о увођењу српског језика у мјесне јавне основне школе у Боки у четвртој деценији XIX вијека, као и у которску вишу основну школу. Он наводи захтјев Бокеља аустријским властима да се „разни српски текстови и уџбеници за православну дјецу који су штампани на славеносербском језику, који та дјеца не разумију, донесу и штампају на српском језику који је у општој употреби, задржавајући ћирилска слова" (Мијушковић 1965: 8). 
Мијушковић говори и о томе како се народ херцегновског среза 1845. године успротивио отварању италијанских школа у Топлој и другим мјестима. У протестним дописима сеоских главара Бијеле, Мојдежа, Кута, Кумбора, Пода, Требесина, Мокрина и Сасовића, као и пароха Топле и Крушевица, поднесеним у времену од 22. јуна до 18. јула 1845, који се чувају у Епархијском архиву у Котору, а које Мијушковић цитира, углавном стоји да је вијест о оснивању италијанских школа у овим мјестима изазвала „веома велику узнемиреност” због тога што се дјеца неће обучавати „на српском већ на страном језику”; да се дозволи паросима да они одржавају школу на српском језику док се не оснују јавне српске основне школе; да се издејствује отварање српских школа у којима ће учитељи бити српске народности и вјере, који ће зависити од православног епископа и који ће бити оспособљени да наставу воде на српском језику итд. (Мијушковић 1965: 12).

Свештеник Јаков Поповић, провикар далматинског епископа за Боку Которску, у писму од 7. јануара 1847. тражи од аустријских власти увођење наставе на српском језику у свим бокељским школама, јер „Касателно материна језика то је познато да у Боки јест серпски матерњи језик, то овај мора се вообшче, без разликости вјере, и учити по смислу рјешенија Министеријума. (...) Нико не може опровергнути или противорјечити да није амо сербски материн језик; зато дакле по свима школама морају се завести наставленија како језиком тако и буквами сербскими (кириловини)" (Мијушковић 1965: 14). А општина которска у једном акту од 10. новембра 1847. наводи да су которски православци и неки католици изјавили да је како у самом Котору тако и у читавој Боки матерњи језик српски који се пише ћирилским словима, „која су најприкладнија за његово писање и изговарање”, па су стога тражили „да се још у току школске године уведе у првом разреду настава на српском језику и ћирилским словима" (Мијушковић 1965: 15). Послије ових навода, општина у истом пропратном акту тврди „да не постоји сумња да је матерњи језик у Котору и Боки српски, те да се он на основу декрета Министарства просвјете има увести као наставни језик у которској вишој основној школи" (Мијушковић 1965: 16).

Вриједан документ о матерњем језику (и етничкој припадности) Бокеља јесте и писмо бокељских главара (њих око четиристо, међу којима је био и Стефан Митров Љубиша, као и начелник прчањски Антон Сбутега) Хрватско-славонском сабору у Загребу, упућено 1/13. јуна 1848. године из Прчања. У том писму, поред осталог, бокељски прваци наглашавају да „окружје бококоторско припада по положају, по историји, по језику, и по племену већег броја славенско-српској народности" (Лукетић 1991).

Корак даље у залагању за увођење српског језика изван домена школе которска општина је учинила и приликом расписивања конкурса за општинског 
писара 3. јануара 1867. У конкурсној објави овом приликом је био истакнут изричити услов да кандидати морају „одлично познавати славено-српски језик" (Мијушковић 1965: 26). Употреба термина славено-српски у том конкурсу била је повод за расправу у которској општини о називу народног језика. Присједник, тј. потпредсједник општине Шпиро Бјеладиновић предложио је назив „славено-српски” с образложењем да је „славено-српски језик, којим говоре сусједни Херцеговци и Црногорци, језик которског округа” (Мијушковић 1965: 26), што је прихваћено и изгласано.

Которска општина је 14. јула 1872. доставила Окружном начелству један списак назива локалитета са свог подручја, наглашавајући да су ти називи „написани једном у талијанском језику, а другом, не како ви кажете у далматинскоме језику, којега пишуће не позна исто као и не знаде пук Обћине ове, него баш у правоме нашему матерноме србскоме језику. Ми и наше земље једанкрат смо крштени били, а новог крштења нити питамо, нити примамо; ми и земље наше примили смо крштење од прадједовах наших у србскоме језику" (Мијушковић 1965: 30).

Док су аустријске власти упорно избјегавале да народни језик у Боки Которској именују као српски, наставници овог језика у которској гимназији су у званичним дописима овај језик називали српским и потписивали се као наставници српског језика (Мијушковић 1965: 30). То, на примјер, ради Вук Поповић (пријатељ и сарадник Вука Караџића), као и Ристо Ковачић који свој допис - Молбу предату општинском уреду 28. августа 1872. потписује: „Ристо Ковачић учитељ геогр. хист. и српског језика” (цит. према: Антовић 2007: 199). А 8. октобра 1872. которска општина је обавијестила Окружни суд, Државно одвјетништво и Срески суд у Котору да је одлучила да „за Обћину которску званични језик мора бити једино србски" (Мијушковић 1965: 31).

4. Да је матерњи језик Црногораца и Бокеља српски, потврдили су и научно доказали велики српски лингвисти, који су иначе родом са простора данашње Републике Црне Горе: Радосав Бошковић, Михаило Стевановић, Радомир Алексић, Јован Вуковић, Лука Вујовић, Милија Станић, Митар Пешикан, Драго Ћупић, Драгољуб Петровић, Мато Пижурица, Бранислав Остојић, Радмило Маројевић.

Након Другог свјетског рата, у дужем временском периоду питање службене употребе језика није било прецизно уставно ријешено. Устав Народне Републике Црне Горе, који је усвојила Уставотворна скупштина на Цетињу 31. децембра 1946. године, није дефинисао назив службеног језика. Међутим, У десетом поглављу тог Устава - Народни судови, у члану 113. изричито се каже: „Поступак пред судовима води се на српском језику”(Устав 1947: 33).

Уставом Републике Црне Горе из 1992. године питање службене употребе језика било је ријешено чланом 9, чији је први став гласио: „У Црној Гори 
у службеној употреби је српски језик ијекавског изговора" (Устав 1997: 99). Међутим, од 1997. године актуелни црногорски режим и његови идеолошки ментори (од којих су неки 1992. били „уставотворци”) чине све да затру име српском језику. Покренута је најшира могућа кампања за уставно преименовање језика у Црној Гори. Та кампања је резултирала данашњим Уставом Црне Горе, који је 18. октобра 2007. прогласила Уставотворна скупштина Републике Црне Горе. Тим уставом је „црногорски језик” озакоњен као службени језик у Црној Гори. Наиме, члан 13. овог устава, који регулише питање службене употребе језика и писма, у цјелини гласи: „Службени језик у Црној Гори је црногорски језик. Ћирилично и латинично писмо су равноправни. У службеној употреби су и српски, босански, албански и хрватски језик" (Устав 2007: 14). Да је ријеч о par excellence политичком, а никако лингвистичком питању, потврђују и сами иницијатори и протагонисти овог етноцидног подухвата.

Намјера да се матерњи језик Црногораца и Бокеља третира као некакав „црногорски језик”, није ништа друго до великохрватска идеолошка манипулација. Наиме, стварање тзв. црногорског језика и потискивање ћириличног писма само је један од аспеката хрватског великодржавног империјалног пројекта који Црну Гору види као интегрални дио хрватског етничког, историјског, културног и језичког корпуса (о томе опширније у: Алексић 2002). Да је управо о томе ријеч, потврђује и један од идеолога латинизације и кроатизације Црногораца, Рајко Церовић, који у културном додатку дневног листа Vijesti од 3. маја 2003. године, у полемици с академиком Браниславом Остојићем, истиче да „Црногорци говоре хрватским, у најмању руку толико колико и српским, или да будемо прецизнији, због ијекавице говоре више хрватским него српским језиком" (Церовић 2003).

Осим тога, није нимало случајно што је „творац” тзв. црногорског језика и правописа - Војислав П. Никчевић, у својим пропагандистичким (и највећим дијелом расистичким) текстовима, у којима се бавио надрилингвистиком (Никчевић В. 1998а; Никчевић В. 1998б), највише волио да цитира др Ива Пилара, свакако најобразованијег и најутицајнијег хрватског усташког идеолога између два свјетска рата. Конкретно, најчешће је цитирао његове великохрватске тезе из књиге Јужнославенско питање и Свјетски рат приказ ијелокупног стања, коју је објавио у Бечу 1918. под псеудонимом L. V. Südland. (Друго издање ове књиге крцате фалсификатима објавила је Матица хрватска у Загребу 1943. године, а треће издање објављено је деведесетих година прошлог вијека, у Вараждину (Пилар 1990)).

Да је Војислав Никчевић био миљеник хрватске националистичке интелигенције свједочи и чињеница да су његове надрилингвистичке „пројекте”2

${ }^{2}$ О Никчевићевој „лингвистичкој науци” видјети у приказима Милоша Ковачевића и Михаила Шћепановића на Граматику ирногорског језика, В. Никчевића, и на књигу Романизми и грецизми 
свим силама подупирале хрватске националистичке институције и организације попут Матице хрватске, Савеза црногорских удруга Хрватске и Хрватско-црногорског друштва пријатељства „Кроатика - Монтенегрина”. Тако је у њиховој организацији 5. децембра 2002, у просторијама Матице хрватске у Загребу, уприличена промоција Никчевићевих књига (или како су то организатори назвали „представљање пројеката”) Црногорски правопис и Црногорска граматика. На промоцији су говорили истакнути хрватски националистички идеолози и ,језикословци”: академик Јосип Братулић (тадашњи предсједник Матице хрватске), проф. др Јосип Силић, проф. др Иво Прањковић и проф. др Марко Самарџија. Ријеч је о ,језикословцима” који су по инструкцијама Туђмановог режима почетком деведесетих година прошлог вијека радили на „чишћењу” хрватског језика од „србизама” и на увођењу смијешних неологизама угледајући се на језички пуризам који је био спроведен у Павелићевој Независној Држави Хрватској. Никчевић се, несумњиво, на њих угледао када је у свој „црногорски језик”, умјесто „србизама” уносио кроатизме и архаизме, и кад је умјесто црногорско-херцеговачког типа ијекавице фаворизовао хрватски тип (што се посебно огледа у форсирању група рије и рје - приједлог, пријевоз, пријенос, грјехота, рјеђи, - из типа ијекавице који се пропагира у Хрватској, на штету црногорско-херцеговачког е - предлог, пренос, превоз, грехота, ређи).

Да је преименовање српског језика у тзв. црногорски, које је спроводио данас већ бивши црногорски режим, дио хрватског национално-политичког пројекта потврђује и чињеница да је поменути хрватски лингвиста др Јосип Силић аутор уџбеника Црногорски језик (с поднасловом Научно-методолошке основе стандардизације црногорскога језика) објављеног 2010. године у издању Министарства просвјете и науке Црне Горе. Ова књига је штампана у 8.000 примјерака и дијељена је бесплатно уз примјерак дневног листа Побједа. Осим тога, др Јосип Силић и др Иво Прањковић су аутори Граматике црногорскога језика, објављене 2010. такође у издању Министарства просвјете и науке Црне Горе. Као првог аутора ове књиге Прањковић и Силић су дописали Аднана Чиргића, који је познат из штампе као „први доктор црногорског језика" (докторат је стекао у Осијеку пред комисијом у којој није био - нити је могао бити - ни један доктор „црногорског језика”). Ова „граматика” је скоро истовјетна са Силићевом и Прањковићевом Граматиком хрватскога језика, објављеном 2005. у Загребу у издању Школске књиге. По ријечима др Милоша Ковачевића, „највећа разлика између ових граматика је што се на корицама сада појављује име Аднана Чиргића, и то као првог аутора" (цит. према: Сретеновић 2010).

y ирногорском језику, Бранка Шоћа (Ковачевић/Шћепановић 2001) или у посебном сепарату под насловом „Товари лингвистичких несувислости” (2002), као и у приказу Драгољуба Петровића на Никчевићеву књигу Црногорски језик (Петровић Д. 1996б). 
5. На основу свега до сада казанога може се закључити да је веома погубно, лингвистички недопустиво и за Црногорце и Бокеље политички и културно геноцидно уставно преименовање српског језика у тзв. црногорски језик. За Црногорце и Бокеље, односно за српски православни народ на простору данашње Црне Горе, српски језик је услов очувања њиховог историјског идентитета. Од настанка првих цивилизација и формирања правне свијести зна се да је затирање језика представљало израз најсуровијег насиља над људима. Јер, одувијек су народ и језик једно биће (Етнос и Логос). Стога је свака империјалистичка политика у својим покушајима одузимања идентитета неком народу настојала да затре његов језик. Црногорци и Бокељи који се нијесу одрекли свог српског идентитета данас су у положају који описује претходно изречена реченица.

Завршићемо овај рад са двије терминолошке напомене. Називи славено-српски (народ, језик) и српски (народ, језик) представљају синониме. Назив српски језик, историјски гледано, има јединствено, нерашчлањено значење (и народ, и језик којим тај народ говори), па је то одражено и на првом попису становништва у Књажевини Црној Гори 1909. године: етничка припадност је одређена према матерњем језику!

\section{ЛИТЕРАТУРА}

Алексић 2002: Будимир Алексић, Црвено-Црна Гора - о унијаћењу и кроатизачији Црне Горе некад и сад, Никшић: Омладински интелектуални центар.

Алексић 2008: Будимир Алексић, Матерњи језик Црногораца је - српски, Српски језик, XIII/1-2, 641-646.

Алексић 2016: Будимир Алексић, (прир.), Буквар инока Саве Дечанца и игумана Стефана од Паштровића из 1597. године (фототипско издање), Буљарица: Манастир Градиште.

Антовић 2007: Дарко Антовић, Побједа српског народног језика за вријеме аустроугарске владавине у Котору 1872. године, Српски језик, XII/1-2, 179-206.

Барбалић 1933: Fran Barbalić, Peroj-srpsko sečo u Istri, Zagreb: Zaklada tiskare Narodnih novina, 1933, (репринт:) Pula: Srpska pravoslavna crkvena opština pulska i perojska, 2002.

Гојнић 1999: Владо Гојнић, Црногорци у америчким рудокопима, Цетиње: Обод. 
Дабановић 2012: Петар Дабановић, Штап користи само у „васпитне” сврхе, Дан, Подгорица, 18. јануар 2012, XII.

Драгићевић 1952: Р(исто) J. Д(рагићевић), Књаз Данило тражи из Србије професора за српски језик, Историски записи, Цетиње, V, књ. VIII/4-12, 371-372.

Дурковић Јакшић 1980: Љубомир Дурковић-Јакшић, Епископ жички Никифор Максимовић и млади Његош, Краљево: Епархијски управни одбор православне епархије жичке.

Закон о школама 1911: Закон о народнијем школама у Краљевини Црној Гори, друго издање, Цетиње: Државна штампарија.

Јовановић 1986: Батрић Јовановић, Црногории о себи, Београд: Народна књига.

Ковачевић/Шћепановић 2001: Милош Ковачевић, Михаило Шћепановић, Товари лингвистичких несувислости, Српски језик, VI, 621-643.

Лукетић 1991: Мирослав Лукетић, Концепт писма бокељских главара Хрватско-славонском сабору 1848. године, у: Зборник радова са научног скупа „, Уједињење Црне Горе и Боке Которске 1813-1814. године”, одржаног у Котору 10-12. новембра 1988, Титоград: Историјски институт СР Црне Горе.

Маројевић 2019а: Радмило Н. Маројевић, Његошева пјесма у потпису: („Име ми је Верољуб...”), Гласник Одјељења хуманистичких наука Црногорске академије наука и умјетности, 5, 171-183.

Маројевић 2019б: Радмило Маројевић, Политолингвистика и српски језик (српска политика о етносу, језику, књижевном стандарду и писму), уредио и за штампу припремио Душко Певуља, Бања Лука: Бесједа.

Мартиновић 2009: Душан Мартиновић, Тестаменти знаменитих личности и ирквених великодостојника Црне Горе, Подгорица: Црногорска академија наука и умјетности.

Мијушковић 1965: Славко Мијушковић, Борба за српски језик у Котору за вријеме аустријске владавине, Историјски записи, Подгорица, XVIII, књ. XXII, св. 1, 5-33.

Никчевић B. 1998a: Vojislav Nikčević, Jezik je i politika, Monitor, Podgorica, br. 407, 7. avgust 1998, 42-43.

Никчевић В. 1998б: Vojislav Nikčević, Osvajačka lingvistika, Monitor, Podgorica, br. 409, 21. avgust 1998. 
Никчевић М. 1992: Milorad Nikčević, U crnogorskom Ustavu crnogorski jezik", Monitor, Podgorica, 31. jul 1992, br. 93, 9.

Павићевић 2011: Свети Петар Цетињски је говорио српски, приредио Обрад-Раде В. Павићевић, Дан, Подгорица, 18. април 2011, 24.

Петровић Д. 1996а: Драгољуб Петровић, Школа немуштог језика, Нови Сад: Цветник.

Петровић Д. 1996б: Драгољуб Петровић, Обеспамећена лингвистика, Гласник одјељења умјетности Црногорске академије наука и умјетности, 15, 161-178.

Петровић Р. 1997: Растислав В. Петровић, Владика Данило и владика Сава (1697-1781), Београд: Стручна књига.

Петровић-Његош 2001: Принц Михаило Петровић-Његош, Из мојих мемоара, Цетиње: Светигора.

Пилар 1990: L. V. Südland (= Ivo Pilar), Južnoslavensko pitanje — prikaz cjelokupnog stanja, Varaždin: Hrvatska demokratska stranka, podružnica u Varaždinu.

Поповић 1897: Читанка за други разред основнијех школа, саставио Ђуро Поповић, Цетиње: Државна штампарија.

Поповић/Рогановић 1895: Земљопис Кьажевине Црне Горе за ученике трећег разреда основне школе, написали Ђуро Поповић и Јован Рогановић, Цетиње: Државна штампарија, 1895, (репринт:) Андријевица: Ступови, 1997.

Ровински 2004: Павел Аполонович Ровински, Црна Гора у прошлости и садашњости, том III, Етнографија - књижевност и језик, превела с руског Видосава Стојановић, Цетиње: Обод.

Силић 2010: Јосип Силић, Црногорски језик (научно-методолошке основе стандардизачије ирногорскога језика), Подгорица: Министарство просвјете и науке Црне Горе.

Сретеновић 2010: Мирјана Сретеновић, С́ура ћемо се наћи у ресторану, Политика, Београд, 13. септембар 2010, 13.

Стојановић 2016: Јелица Стојановић, Пут српског језика и писма, Београд: Српска књижевна задруга.

Стојковић 2008: Славо Стојковић, Медитеранска загонетка (Бока и Бокељи), Херцег Нови: Градска библиотека и читаоница.

Сидланд Л. В. - види Pilar 1990. 
Устав 1947: Устав Народне Републике Црне Горе. Цетиње: Штампарско-издавачко предузеће НРЦГ, „Обод”.

Устав 1997: Устав Републике Србије и Устав Републике Црне Горе са уставним законима за ғихово спровођење. Београд: Службени лист СРЈ.

Устав 2007: Ustav Crne Gore. Podgorica: Službeni list Crne Gore.

Церовић 2003: Rajko Cerović, Srbocentrično shvatanje jezika, Vijesti, Podgorica, 3. maj 2003, 11.

Чиргић/Прањковић/Силић 2010: Аднан Чиргић, Иво Прањковић, Јосип Силић, Граматика ирногорскога језика, Подгорица: Министарство просвјете и науке Црне Горе.

Џомић 2013: Велибор Џомић, Црква и држава у Црној Гори, Цетиње: Светигора; Подгорица: Октоих; Београд: Штампар Макарије.

Шијаковић 2011: Богољуб Шијаковић, Огледање у контексту, Београд: Службени гласник.

Шпадијер 1900: Ђуро Шпадијер, Српска граматика за трећи и четврти разред основнијех школа у Кнажевини Црној Гори, Цетиње: Државна штампарија.

\section{ON THE NAMING OF LANGUAGE IN THE PAST OF MONTENEGRO AND THE BAY OF KOTOR}

\section{Summary}

This work discusses the issue of naming the mother language in the past of Montenegro and the Bay of Kotor. Analysis of preserved sources from the fifteenth century to the present day led us to a conclusion that Montenegrins and Bokels always called their language Serbian (and never Montenegrin). We have also found that all historical facts irrefutably prove and confirm that the Serbian language was in official use in the Kingdom of Montenegro for the entire period of its duration.

Key words: Serbian language, Serbian people, Cyrillic alphabet, Montenegro, Bay of Kotor, official use of language. 